\title{
Dochodzenie roszczeń wynikających z przewlekle prowadzonego postępowania sądowego
}

\section{Wprowadzenie}

\azzyscy muszą liczyć się z ryzykiem bycia stroną postępowania sądowego. wspólnego, czy też praw i wolności innej jednostki. Leżący po stronie państwa konstytucyjny obowiązek zapewnienia bezpieczeństwa i porządku, związany jest z możliwością wszczęcia i prowadzenia postępowania karnego względem jednostki. Także zagwarantowane każdemu konstytucyjne prawo do drogi sądowej w przypadku naruszenia wolności lub praw jednostki, wskazuje nieuchronnie na możliwość stania się stroną sporu w sprawie cywilnej zarówno po stronie powodowej, jak i pozwanej. Wychodząc z założenia, że poza nielicznymi osobami czy też podmiotami profesjonalnie trudniącymi się sprawami sądowymi, inni odczuwają dyskomfort biorąc udział w postępowaniu sądowym, wypada sformułować postulat jego szybkiego przeprowadzenia, żeby niedogodności z nim związane trwały jak najkrócej. Z drugiej strony obowiązkowi wydania sprawiedliwego wyroku czy też konieczności zapewnienia stronie w prowadzonym postępowaniu sądowym szeregu gwarancji procesowych może nie sprzyjać idea jego szybkiego zakończenia. W tym zakresie wyrażone w art. 45 Konstytucji ${ }^{1}$ prawo do sądu wskazuje nie tyle na konieczność szybkiego rozpoznania sprawy, co bez wątpienia byłoby pożądane, ale też na konieczność rozpatrzenia jej bez nieuzasadnionej zwłoki. Także kompromis pomiędzy sprawiedliwym a szybkim

\footnotetext{
* Dr Katarzyna Ciućkowska - Uniwersytet Warmińsko-Mazurski w Olsztynie, Wydział Prawa i Administracji, Katedra Prawa Cywilnego; e-mail: katarzyna.ciuckowska@gmail.com.

${ }^{1}$ Konstytucja Rzeczypospolitej Polskiej z 2 kwietnia 1997 r. (Dz. U. 1997, nr 78, poz. 483 ze zm.).
} 
procesem znajduje swoje urzeczywistnienie w wyrażonym w art. 6 ust. 1 Konwencji o ochronie praw człowieka i podstawowych wolności ${ }^{2}$ prawie do rzetelnego procesu sądowego poprzez postulat rozpatrzenia sprawy w rozsądnym terminie. Podobnie Międzynarodowy Pakt Praw Obywatelskich i Politycznych ${ }^{3}$ w art. 14 ust. 3 lit. c. daje gwarancję do przeprowadzenia rozprawy bez nieuzasadnionej zwłoki osobie oskarżonej o popełnienie przestępstwa.

Czas, w jakim sprawa zostanie rozpatrzona, stanowi zatem istotny element chronionego konstytucyjne prawa do sądu, czy też - na gruncie prawa międzynarodowego - prawa do rzetelnego procesu. W związku ze specyfiką i indywidualnym charakterem każdej ze spraw sądowych, konstruowanie wzorcowego abstrakcyjnego modelu przebiegu pewnego typu postępowań sądowych ze wskazaniem pożądanego czasu ich trwania, jakkolwiek kuszące, może w konfrontacji z rzeczywistością zawodzić. Stąd też stwierdzenie czy długość toczącego się postępowania sądowego nie nadwyręża zasady prawa do sądu, wymaga indywidualnej oceny każdej ze spraw. Tak też w kontekście postulatu sprawnego rozpatrzenia sprawy pojawia się pojęcie przewlekłości postępowania, jako sytuacji niepożądanej, która wykracza daleko poza wspomniany obowiązek znoszenia przez jednostkę faktu toczącego się postępowania sądowego, w którym jest ona stroną.

Niniejszy artykuł dotyka problematyki długości postępowań sądowych w kontekście oceny ich przewlekłości, odnosi się do charakteru i zakresu możliwych do sformułowania roszczeń wynikających z przewlekle prowadzonych postępowań. Chodzi tu nie tylko o skargę na przewlekłość postępowania, ale szerzej również o roszczenia odszkodowawcze dotyczące naprawienia szkody majątkowej oraz niemajątkowej. Celem pracy jest przedstawienie omawianego problemu także z perspektywy regulacji cywilnoprawnych przy uwzględnieniu specyfiki tego typu spraw oraz zwrócenie uwagi na problemy, jakie mogą pojawić się przy dochodzeniu roszczeń wynikających z przewlekle prowadzonych postępowań.

\section{Pojęcie przewlekłości postępowania}

Dokonanie oceny, czy długość toczącego się postępowania jest uzasadniona koniecznością rzetelnego rozpatrzenia sprawy, czy też przerodziło się ono już w postępowanie przewlekłe, wydaje się, że powinno nastąpić nie tylko na

${ }^{2}$ Konwencja o ochronie praw człowieka i podstawowych wolności sporządzona w Rzymie 5 listopada 1950 r., zmieniona następnie Protokołami nr 3, 5 i 8 oraz uzupełniona Protokołem nr 2 (Dz. U. 1993, nr 61, poz. 284 ze zm.).

${ }^{3}$ Międzynarodowy Pakt Praw Obywatelskich i Politycznych otwarty do podpisu w Nowym Jorku dnia 19 grudnia 1966 r. (Dz. U. 1977, poz. 38, nr 167). 
podstawie wzorca obiektywnego, ale także mając na względzie okoliczności konkretnej sprawy i jej indywidualny charakter. Zawarty w prawie do sądu postulat rzetelnego i sprawiedliwego rozpatrzenia sprawy, nie zawsze musi bowiem iść w parze z szybkością postępowania. Należy także mieć na uwadze, że wzmocnienie zasady szybkości postępowania niestety mogłoby w niektórych przypadkach osłabiać jego rzetelność. Ustalenie przewlekłości postępowania w konkretnej sprawie przez pryzmat modelowo stworzonego wzorca (np. postępowanie w jednej instancji może trwać najdłużej jeden rok, a w przypadku przekroczenia tego terminu dochodzi do przewlekłości postępowania), może zawodzić w sytuacji pojawienia się zdarzeń szczególnych, takich jak śmierć strony i konieczność zawieszenia postępowania cywilnego z tego powodu, czy mnogość lub długość wydawania opinii przez biegłych. Niezależnie od powołanych wyżej argumentów samo stworzenie takiego wzorca wydaje się być pożądane $\mathrm{z}$ punktu widzenia nauki.

Ustawodawca zajął się bliżej problemem przewlekłości postępowania dopiero w wyniku sprawy Kudła przeciwko Polska ${ }^{4}$, w której Europejski Trybunał Praw Człowieka zwrócił uwagę na brak w polskim systemie prawnym środka służącego zapobieżeniu lub właściwemu reagowaniu na naruszenia prawa do rozpoznania sprawy w rozsądnym terminie ${ }^{5}$. Na kanwie tej sprawy od $2004 \mathrm{r}$. w polskim systemie prawnym pojawiła się regulacja ustawowa dotycząca skargi na przewlekłość postępowania ${ }^{6}$. Konieczność wprowadzenia takiego środka prawnego, wymusiła na ustawodawcy doprecyzowanie konstytucyjne zagwarantowanego prawa do rozpoznania sprawy bez nieuzasadnionej zwłoki oraz wskazania kryteriów pozwalających na ocenę, czy w konkretnym postępowaniu doszło do naruszenia tego prawa. Ustawodawca w art. 2 ust. 1 powołanej ustawy wskazał, że do naruszenia prawa do rozpoznania sprawy bez nieuzasadnionej zwłoki dochodzi, jeżeli postępowanie zmierzające do wydania rozstrzygnięcia kończącego postępowanie trwa dłużej niż to konieczne dla wyjaśnienia istotnych okoliczności faktycznych i prawnych. Sytuację, w której wyżej sformułowane prawo zostało naruszone, określa się jako przewlekłość postępowania.

Do kryteriów, którymi winien kierować się sąd przeprowadzając ocenę, czy w sprawie doszło do przewlekłości postępowania należą terminowość i prawidłowość czynności podjętych przez sąd w celu wydania rozstrzygnięcia kończącego

${ }^{4}$ Wyrok Europejskiego Trybunału Praw Człowieka z 26 października 2000 r. w sprawie nr 30210/96 Kudła przeciwko Polsce (LexPolonica nr 384839).

${ }^{5}$ Szerzej zob. B. Gronowska, Wyrok Europejskiego Trybunału Praw Człowieka w sprawie Kudła przeciwko Polsce - dotyczacy czasu i warunków stosowania aresztu tymczasowego, sprawności procesu karnego oraz prawa do skutecznego środka odwoławczego, „Prokuratura i Prawo” 2001, nr 1, s. 119-125.

${ }^{6}$ Ustawa z 17 czerwca 2004 r. o skardze na naruszenie prawa strony do rozpoznania w postępowaniu przygotowawczym prowadzonym lub nadzorowanym przez prokuratora i postępowaniu sądowym bez nieuzasadnionej zwłoki (tj. Dz. U. 2016, poz. 1259), dalej także w skrócie jako „ustawa”. 
postępowanie w sprawie (art. 2 ust. 2 ustawy), chociaż należy wskazać, że nie jest to katalog zamknięty, na co wskazuje sformułowanie „w szczególności”. Ocena - jak wskazuje ustawodawca, dokonywana jest przy uwzględnieniu przesłanki czasu, stopnia faktycznej i prawnej zawiłości, znaczenia sprawy dla strony, która wniosła skargę oraz zachowania się stron w postępowaniu (art. 2 ust. 2 ustawy). Ustalenie zatem czy w sprawie mamy do czynienia z przewlekle prowadzonym postępowaniem pozostawiono uznaniu sądu, wskazując ogólne ramy zakresu i sposobu przeprowadzenia takiej oceny. W konsekwencji subiektywne elementy sprawy wyrażające się w jej indywidualnym charakterze, mogą stanowić podstawę ustalenia czy sprawa rozstrzygana jest bez nieuzasadnionej zwłoki

Judykatura w tym zakresie reprezentuje w zasadzie zgodny pogląd, że przy ocenie czy postępowanie ma charakter przewlekły, decydować powinny okoliczności konkretnej sprawy ${ }^{8}$. Zwraca się jednak uwagę na potrzebę uwzględnienia obiektywnych i ustawowych kryteriów w odniesieniu do realiów faktycznych i prawnych sprawy, a sama długotrwałość postępowania nie musi oznaczać, że doszło do jego przewlekłości. Orzecznictwo dopuszcza także dokonanie oceny konkretnego postępowania przez przyrównanie go do modelu wzorcowego. Wyrazem tego jest stanowisko judykatury, że zasadniczo za przewlekłe uznaje się postępowanie, w którym w danej instancji nie wyznaczono rozprawy przez ponad dwanaście miesięcy, czy gdy od czasu wpływu apelacji do Sądu drugiej instancji do daty pierwszego terminu rozprawy drugoinstancyjnej minęło osiem miesięcy ${ }^{9}$, chociaż w tym zakresie aktualnie zaczyna przeważać pogląd, że o przewlekłości w postępowaniu przed Sądem drugiej instancji mówimy, gdy bezczynność polegająca na niewyznaczeniu rozprawy apelacyjnej trwa co najmniej dwanaście miesięcy ${ }^{10}$. Ponadto wskazuje się w orzecznictwie, że sprawy z zakresu ubezpieczeń społecznych, jako te związane z dostarczeniem środków pieniężnych do życia, winy być rozpatrywane ze szczególną pilnością ${ }^{11}$.

7 Cz. P. Kłak, Pojęcie przewlekłości postępowania sądowego, „Prokuratura i Prawo” 2008, nr 12, s. 73, który wskazuje, że ustawa odwołuje się do uwarunkowań obiektywnych, a źródło nieporozumienia może stanowić pomylenie kryteriów ustawowych z oceną realiów konkretnej sprawy.

${ }_{8}^{8}$ Zob. postanowienie Sądu Najwyższego z 28 maja 2015 r., III SPP 10/15 (1740741); z 4 kwietnia 2017 r., III SPP 13/17 (Lex nr 2298290); wyrok Sądu Apelacyjnego we Wrocławiu z 30 września 2013 r. (Lex 1378927).

9 Zob. postanowienie Sądu Najwyższego z 8 maja 2013 r., III SPP 51/13 (Lex 1555679); z 17 grudnia 2013 r., III SPP 242/13 (Lex 1555675).

${ }_{10}$ Postanowienia Sądu Najwyższego z 12 maja 2005 r., III SPP 96/05, OSNP 2005, nr 23, poz. 384; z 18 maja 2016 r., III SPP 53/16, niepublikowane; z dnia 22 marca 2017 r., III SPP 7/17 (Lex 2300161); z dnia 4 kwietnia 2017 r., III SPP 13/17 (Lex 2298290).

${ }_{11}$ Zob. postanowienia Sądu Najwyższego z 8 marca 2005 r., III SPP 34/05 (Lex 156663); z 6 stycznia 2006 r., III SPP 154/05, OSNP 2006, nr 21-22, poz. 342; oraz z 10 sierpnia 2007 r., III SPP 31/07, OSNP 2008, nr 21-22, poz. 336. 
Zwrócić jeszcze należy uwagę, że za okoliczności usprawiedliwiające długi czas rozpatrywania sprawy nie mogą zostać uznane problemy i trudności ekonomiczne, kadrowe, organizacyjne czy inne leżące po stronie wymiaru sprawiedliwości. Argumenty takie nie są uznawane za stanowiące wystarczającą podstawę do ograniczenia prawa strony rozpatrzenia jej sprawy bez nieuzasadnionej zwłoki i nie ekskulpują sądu od odpowiedzialności za przewlekłość postępowania ${ }^{12}$. Wynika to $\mathrm{z}$ tego, że to państwo ma obowiązek zorganizowania warunków należytego sprawowania władzy jurysdykcyjnej, tak aby zapewnić obywatelom poszanowanie ich praw gwarantowanych konstytucyjnie ${ }^{13}$.

W judykaturze można także spotkać się ze stanowiskiem, że przewlekłość postępowania zachodzi nie tyle wówczas, gdy pojawia się sama zwłoka w czynnościach, a wtedy gdy ma ona charakter rażący i nie znajduje uzasadnienia w obiektywnych okolicznościach spraw $y^{14}$. Także wadliwe podjęcie czynności i zwłoka powstała $z$ tego tytułu może uzasadniać przyjęcie naruszenia prawa do rozpoznania sprawy w rozsądnym terminie ${ }^{15}$. $Z$ drugiej strony do stwierdzenia przewlekłości nie jest niezbędne istnienie winy po stronie organu ${ }^{16}$.

\section{Roszczenia wynikające ze skargi na przewlekłość postępowania}

W przypadku naruszenia prawa strony do rozpoznania sprawy bez nieuzasadnionej zwłoki na pierwszy plan wyłania się możliwość wystąpienia ze skargą na przewlekłość postępowania. Wypada jednak zaznaczyć, że funkcją skargi jest przede wszystkim zdyscyplinowanie sądu i wymuszenie nadania sprawie odpowiedniego sprawnego biegu, a element kompensacyjny w tym przypadku schodzi na dalszy plan. Zgodnie jednak $\mathrm{z}$ art. 12 ustawy w przypadku uwzględnienia skargi przyznawana jest stronie suma pieniężna w wysokości od 500 do 20000 zł. Pewne kontrowersje budzi określenie charakteru prawnego przyznanej z tego tytułu kwoty pieniężnej ${ }^{17}$. Aktualnie ocenia się ją jako szczególny rodzaj sankcji za naruszenie prawa strony do sądu, który ma dyscyplinować sąd,

12 Wyrok Sądu Apelacyjnego w Warszawie z 9 października 2012 r., II S 58/12 (Lex 1220706).

13 Por. postanowienie Sądu Najwyższego z 21 marca 2006 r., III SPP 13/06, OSNP 2007, nr 7-8, poz. 121.

${ }_{14}$ Postanowienie Sądu Apelacyjnego we Wrocławiu z 14 marca 2012 r., II S 8/12 (Lex 1127084).

15 Por. postanowienie Sądu Najwyższego z 2 marca 2012 r., KSP 1/12 (Lex 1165252).

16 Por. postanowienie Sądu Najwyższego z 17 grudnia 2013, III SPP 242/13 (Lex 1555675).

17 Szerzej J. Kuźmicka-Sulikowska, Suma pieniężna przyznawana z tytułu przewlekłości postępowania, [w:] „Aktualne zagadnienia prawa prywatnego”, red. E. Marszałkowska-Krzyś, Wrocław 2012, s. 85-111 i literatura tam powoływana. 
a zarazem stanowić pewnego rodzaju „słuszne zadośćuczynienie”18. Stąd też suma pieniężna przyznawana tytułem przewlekłości postępowania nie ma ani charakteru odszkodowania rozumianego jako rekompensata szkody majątkowej, nie stanowi także zadośćuczynienia za krzywdę spowodowaną naruszeniem zdrowia czy innych dóbr osobistych ${ }^{19}$. W orzeczeniu z 22 marca 2017 r. Sąd Najwyższy wskazał, że odpowiednia suma pieniężna pełni rolę swoistego rodzaju zadośćuczynienia za stres i frustrację wywołaną przewlekłością postępowania sądowego i stanowi rekompensatę dla skarżącego za krzywdę moralną tym spowodowaną ${ }^{20}$. Jej wysokość ustala się w wysokości proporcjonalnej do wielkości zwłoki, jej przyczyn oraz dolegliwości dla skarżącego ${ }^{21}$.

Mając na uwadze przede wszystkim funkcję dyscyplinującą skargi na przewlekłość postępowania i wyłącznie słuszny charakter zasądzanej z tego tytułu sumy pieniężnej, zresztą ograniczony przez ustawodawcę do pewnej wysokości, pełna kompensata szkody wynikłej z przewlekłości może nastąpić zasadniczo w odrębnym postępowaniu, w którym na zasadach ogólnych pokrzywdzony będzie mógł dochodzić zasądzenia odszkodowania lub zadośćuczynienia. Wyraża to wprost art. 15 i 16 ustawy, chociaż jak się wydaje nie stanowią one norm kształtujących, a możliwość konstruowania roszczeń wynikających z przewlekłości postępowania w oparciu o art. 417 k.c. można wyprowadzić także z zasad ogólnych. W związku z tym w judykaturze wskazuje się, że regulacje zawarte w art. 15 i 16 ustawy mają tylko charakter norm odsyłających czy kolizyjnych ${ }^{22}$. Specyfika dochodzenia roszczeń wynikających z przewlekłości postępowania na zasadach ogólnych zostanie omówiona w dalszej części pracy, w tym miejscu wypada jeszcze wspomnieć o art. 15 ustawy i wskazanym tam prejudykacie.

Należy zaznaczyć, że zgodnie z art. 15 ustawy uwzględnienie skargi na przewlekłość postępowania otwiera stronie możliwość wystąpienia w osobnym postępowaniu o naprawienie szkody wynikającej z przewlekłości na zasadach ogólnych i to jeszcze w trakcie trwania postępowania, w którym nastąpiła przewlekłość. Uwzględnienie skargi ma charakter prejudykatu, który wskazuje na istnienie bezprawności w rozumieniu art. 417 kodeksu cywilnego ${ }^{23}$, co jednak nie zwalnia strony z wykazania istnienia dalszych przesłanek odpowiedzialności odszkodowawczej, o czym później. Wypada jeszcze zwrócić uwagę, że związanie

${ }_{18}$ M. Pilich, Glosa do wyroku Sadu Apelacyjnego w Katowicach z 9 listopada 2005 r., I ACa 1063/05, OSP 2008, nr 11, s. 841-848.

19 Zob. T. Grzeszak, Przewlekłość postępowania w naruszenie praw osobistych (w orzecznictwie Sądu Najwyższego), „Monitor Prawniczy” 2006, nr 19, s. 1048-1049.

${ }^{20}$ Postanowienie Sądu Najwyższego z 22 marca 2017 r., III SPP 11/17 (Lex 2298289).

${ }^{21}$ Ibidem.

${ }^{22}$ Zob. wyrok Sądu Najwyższego z 26 stycznia 2017 r., I CSK 45/16 (Lex 2269101); wyrok Sądu Apelacyjnego w Katowicach z 8 maja 2015 r., V Aca 279/14 (Lex 1809532).

${ }^{23}$ Ustawa z 23 kwietnia 1964 r. Kodeks cywilny (tj. Dz. U. 2017, poz. 459, 933, 1132), dalej w skrócie „k.c.” 
sądu w odrębnym postępowaniu postanowieniem uwzględniającym skargę nie ma charakteru ogólnego i nie daje podstaw do formułowania wniosku, że całe kwestionowane postępowanie objęte jest przewlekłością. Sąd jest związany tylko w zakresie okoliczności świadczących o przewlekłości, które stanowiły podstawę uwzględnienia skargi i tylko co do tych okoliczności można mówić o istnieniu prejudykatu wskazującego na bezprawność. Ma to istotny wymiar praktyczny, ponieważ art. 15 daje możliwość wystąpienia z roszczeniami odszkodowawczymi jeszcze $\mathrm{w}$ trakcie trwania przewlekle prowadzonego postępowania, w tym przypadku zakres odrębnego postępowania prowadzonego równolegle z postępowaniem przewlekle prowadzonym jest ograniczony tylko co do zdarzeń objętych prejudykatem. Inna sytuacja występuje w przypadku wystąpienia z roszczeniami już po zakończeniu postępowania przewlekle prowadzonego. Wówczas obok kwestii przesądzonych prejudykatem, mogą także pojawić się żądania kompensaty szkody wyrządzonej także innymi działaniami lub zaniechaniami sądu, w których strona upatruje naruszenia prawa do rozpoznania sprawy bez nieuzasadnionej zwłoki, ustalenie czy w tym zakresie zachodzi bezprawność będzie podlegać ocenie sądu.

\section{Roszczenia odszkodowawcze oparte na zasadach ogólnych}

Generalnie otwarcie drogi do dochodzenia rekompensaty szkód powstałych w wyniku przewlekłe prowadzonego postępowania sądowego następuje po prawomocnym zakończeniu tego postępowania. Wówczas, co potwierdza art. 16 ustawy strona może dochodzić naprawienia szkody wynikającej z przewlekłości. Zwrócić należy uwagę, że nie jest przy tym wymagane istnienie prejudykatu, czyli posiadanie postanowienia stwierdzającego istnienie przewlekłości postępowania. Takiej oceny będzie już dokonywał sam sąd w postępowaniu prowadzonym na zasadach ogólnych. Dochodzenie roszczeń wynikających z przewlekłości postępowania na zasadach ogólnych wymaga większego zaangażowania strony niż w przypadku skargi na przewlekłość postępowania. Koniecznym jest tu kumulatywne wykazanie istnienia wszystkich przesłanek odpowiedzialności odszkodowawczej, a ciężar dowodu z w tym zakresie, zgodnie z zasadą wyrażoną $\mathrm{w}$ art. 6 k.c. spoczywa na poszkodowanym (w tym przypadku powodzie). Reżim odszkodowawczy z art. 417 k.c., oparty na zasadzie bezprawności, daje możliwość żądania naprawienia szkody, zarówno majątkowej, jak i niemajątkowej, powstałej na skutek przewlekłości postępowania ${ }^{24}$. Wypada jednak zaznaczyć,

${ }^{24}$ Wyrok Sądu Apelacyjnego w Warszawie z 3 listopada 2016 r., I ACa 1767/15 (Lex 2171265); Z. Banaszczyk [w:] System Prawa Prywatnego. T. 6. Prawo zobowiązań - część ogólna, A. Olejniczak (red.), Warszawa 2014, s. 799. 
że w odniesieniu do żądania zadośćuczynienia art. 417 k.c. wymaga powiązania z art. 445 k.c. lub art. 448 k.c. ${ }^{25}$.

Bezprawnością uruchamiającą odpowiedzialność na podstawie art. 417 k.c. będzie w tym przypadku przewlekłość postępowania, rozumiana jako stan nieakceptowalny i naruszający prawo do sądu, w którym wyrażona została konieczność rozpoznania sprawy bez nieuzasadnionej zwłoki. Uzyskanie odszkodowania $z$ tego tytułu wymaga dodatkowo wykazania dalszych przesłanek odpowiedzialności deliktowej, a zatem szkody majątkowej (rozumianej jako lucrum cessans i damum emergens), która pozostaje w związku przyczynowym rozumianym zgodnie $\mathrm{z}$ art. $361 \$ 1$ k.c.

Trochę bardziej skomplikowana wydaje się być kwestia dochodzenia kompensaty szkody niemajątkowej wywołanej przewlekłością postępowania. W tym przypadku nie można posłużyć się prostym przełożeniem, że wykazanie istnienia przewlekłości daje podstawę do zasądzenia zadośćuczynienia. Zwrócić należy uwagę, że zgodnie z ogólną zasadą prawa cywilnego kompensata szkody niemajątkowej może nastąpić tylko w przypadkach wyraźnie wskazanych w pra$w_{i}{ }^{26}$. Taką podstawę $\mathrm{w}$ przypadku reżimu odpowiedzialności deliktowej dają przepisy art. $445 \mathrm{k} . c$. i $448 \mathrm{k.c.}{ }^{27} \mathrm{~W}$ konsekwencji dopiero wykazanie naruszenia zdrowia lub innych dóbr osobistych może stanowić podstawę do zasądzenia zadośćuczynienia za przewlekłość postępowania. Judykatura wyraźnie odrzuciła zapatrywanie, żeby prawo do sądu mogło stanowić dobro osobiste, uznając je wyłącznie za prawo o charakterze gwarancyjnym, które reguluje funkcjonowanie człowieka w konkretnej sferze aktywności społecznej i które uaktywnia się dopiero w momencie wszczęcia postępowania ${ }^{28}$. Tymczasem za dobro osobiste uznaje się wartości nierozerwalnie związane z jednostką ludzką, mające charakter bezwzględny, towarzyszący człowiekowi przez całe życie, niezależnie od sytuacji w jakiej się znajduje w danej chwilii ${ }^{29}$. Zaznacza się także, że przepisy Konstytucji i Konwencji nie mogą w tym przypadku stanowić samodzielnej podstawy wystąpienia z roszczeniem o zadośćuczynienie za naruszenie prawa do sądu (rozpoznania sprawy bez nieuzasadnionej zwłoki czy rozpoznania sprawy w rozsądnym terminie) $)^{30}$.

25 T. Grzeszak, op. cit., s. 1049.

26 Szerzej E. Bagińska, Poland: Developments in Personal Injury Law in Poland: Shaping the Compensatory Function of Tort Law, „Journal of Civil Law Studies” 2015, vol. 8, nr 1, s. 317.

27 Można tu jeszcze wskazać art. $446 \$ 4$ k.c. dotyczący zadośćuczynienia za śmierć osoby najbliższej, jednak będzie on miał zastosowania do specyfiki spraw odnoszących się do przewlekłości postępowania.

${ }_{28}$ Wyrok Sądu Najwyższego z 24 września 2015 r., V CSK 741/14, OSNC 2016, nr 7-8, poz. 95.

29 Wyrok Sądu Najwyższego z 6 maja 2010 r., II CSK 640/09, OSNC 2011, nr A, poz. 4.

30 Powoływany wyrok Sądu Apelacyjnego w Warszawie z 3 listopada 2016 r. 
Naruszenie prawa do sądu (rozpoznania sprawy w rozsądnym terminie) może jednak w niektórych przypadkach prowadzić do naruszenia dobra osobistego określonego w art. 23 k.c. Dopiero powiązanie przewlekłości postępowania z naruszeniem konkretnego dobra osobistego i wskazanie, że krzywda stanowi skutki bezprawnej ingerencji w to dobro, może prowadzić do zasądzenia zadośćuczynienia na podstawie art. 445 lub 448 k.c. ${ }^{31} \mathrm{~W}$ konsekwencji istnienie zwłoki w rozpoznaniu sprawy i wynikające stąd naruszenie prawa do sądu, nie będzie w każdym przypadku (pomimo istnienia przesłanki bezprawności) prowadziło do zasądzenia zadośćuczynienia, gdyż taka sytuacja nie może być w każdym przypadku kwalifikowana jako naruszenie dobra osobistego ${ }^{32}$. W tym zakresie dochodzenie roszczeń na podstawie reżimu odpowiedzialności deliktowej istotnie różni się od zasad przyznawania sumy pieniężnej w oparciu o regulacje dotyczące skargi na przewlekłość postępowania, gdzie wyłącznie stwierdzenie istnienia przewlekłości daje podstawę do zasądzenia słusznego zadość uczynienia.

Przechodząc do próby określenia, jakie dobra osobiste mogą zostać naruszone przewlekle prowadzonym postępowaniem, w tym przypadku przywołać należy zdrowie, wolność i godność. W odniesieniu do zdrowia, w pierwszej kolejności zastosowanie znajdą regulacje zawarte $\mathrm{w} \mathrm{z}$ art. $445 \$ 1 \mathrm{w} \mathrm{zw} . \mathrm{z}$ art. 444 k.c., a zatem wykazanie zaistnienia rozstroju zdrowia wywołanego na skutek konkretnie ustalonej przewlekłości postępowania może stanowić podstawę do domagania się zasądzenia zadośćuczynienia za doznaną z tego tytułu krzywdę. W przypadku naruszenia dobra osobistego w postaci wolności wskazuje się na rozumienie tego dobra w jego szerokim znaczeniu, a zatem długotrwałą ingerencję w sposób spędzania czasu, który pozostaje ograniczony toczącym się postępowaniem sądowym. Jak wskazuje T. Grzeszak, aby doszło do naruszenia wolności nie wystarczy tu zwykła przewlekłość, a taka, która istotnie ogranicza aktywność danej osoby ${ }^{33}$. Sporo wątpliwości budzi kwestia naruszenia dobra osobistego w postaci godności. W tym zakresie odwołać należy się do przedstawianych na początku pracy rozważań, że każdy musi liczyć się z ryzykiem bycia stroną postępowania i koniecznością znoszenia tego faktu, chociaż budzić to może negatywne emocje. Dodatkowo należy mieć na uwadze, że - jak wynika ze stanowiska judykatury - sama w sobie przewlekłość postępowania nie narusza dobra osobistego. Zatem w przewlekle prowadzonej sprawie muszą dodatkowo pojawić się szczególnie rażące okoliczności, o charakterze kwalifikowanym, dające podstawę do uznania, że miało miejsce celowe poniżanie, dyskrymino-

\footnotetext{
31 Por. wyrok Sądu Najwyższego z 6 maja 2010 r., II CSK 640/09, (Lex 598758); wyrok Sądu Apelacyjnego w Warszawie z 5 grudnia 2014 r., VI Aca 230/14 (Lex 1661263).

32 Por. powoływany wyrok Sądu Apelacyjnego w Warszawie z 3 listopada $2016 \mathrm{r}$.

33 T. Grzeszak, op. cit., s. 1050.
} 
wanie, obrażanie uczestnika postępowania, czym doszło do naruszenia jego godności ${ }^{34}$.

\section{Zakończenie}

Kończąc podjęte rozważania dotyczące dochodzenia roszczeń wynikających z przewlekle prowadzonych postępowań wypada zwrócić uwagę na wielowymiarowość i wielowątkowość prezentowanego zagadnienia. Autor ma świadomość, że nie wszystkie problemy dotyczące przewlekłości postępowania zostały tu poruszone, jednak nie taki jest też cel niniejszej pracy. Przegląd orzecznictwa i doktryny wskazuje, że jakkolwiek duża praca została wykonana w zakresie rozwiązywania problemów wyłaniających się na gruncie wprowadzonej w 2004 r. do polskiego porządku prawnego skargi na przewlekłość postępowania, tak aktualnie punkt ciężkości w zakresie problemów dotyczących przewlekłości postępowań przeniósł się na kwestie dotyczące dochodzenia roszczeń odszkodowawczych z tego tytułu. Możliwość uzyskania zadośćuczynienia rozpatrywana przez pryzmat naruszenia dobra osobistego a nie samej przewlekłości postępowania, stanowi konstrukcję trudną, co niestety często może prowadzić do uproszczeń i wskazywania naruszenia dowolnego dobra osobistego bez głębszej refleksji i ustalania czy z treści danego dobra osobistego mogą pojawić się prezentowane przez stronę skutki jego naruszenia. Niewątpliwie jest to przestrzeń do dalszego rozwijania tego zagadnienia przez doktrynę i judykaturę.

\section{Bibliografia}

Bagińska E., Poland: Developments in Personal Injury Law in Poland: Shaping the Compensatory Function of Tort Law, "Journal of Civil Law Studies” 2015, vol. 8, nr 1.

Banaszczyk Z. [w:] System Prawa Prywatnego. T. 6. Prawo zobowiq̨zań-część ogólna, A. Olejniczak (red.), Warszawa 2014.

Gronowska B., Wyrok Europejskiego Trybunału Praw Człowieka w sprawie Kudła przeciwko Polsce - dotyczący czasu i warunków stosowania aresztu tymczasowego, sprawności procesu karnego oraz prawa do skutecznego środka odwoławczego, „Prokuratura i Prawo” 2001, nr 1.

Grzeszak T., Przewlekłość postępowania w naruszenie praw osobistych (w orzecznictwie Sądu Najwyższego), "Monitor Prawniczy" 2006, nr 19, s. 1048-1051.

Kłak Cz. P., Pojęcie przewlekłości postępowania sq̨dowego, „Prokuratura i Prawo” 2008, nr 12, s. 73.

Kuźmicka-Sulikowska J., Suma pieniężna przyznawana z tytułu przewlekłości postępowania, [w:] „Aktualne zagadnienia prawa prywatnego", red. E. Marszałkowska-Krzyś, Wrocław 2012.

Pilich M., Glosa do wyroku Sądu Apelacyjnego w Katowicach z 9 listopada 2005 r., I ACa 1063/05, OSP 2008, nr 11, s. 841-848.

${ }^{34}$ Ibidem. 


\section{Streszczenie}

Niniejszy artykuł dotyka problematyki długości postępowań sądowych i przewlekłości postępowań. Odnosi się do konstytucyjnych i konwencyjnych regulacji dotyczących prawa do sądu oraz prawa do rzetelnego procesu, z których wynika prawo do rozpaoznania sprawy w rozsądnym terminie. Także problematyka dotycząca dochodzenia kompensaty szkody majątkowej i niemajątkowej w związku z przewlekłością postępowania objęta została zakresem artykułu.

Słowa kluczowe: prawo do sądu, przewlekłość postępowania, dobra osobiste, odszkodowanie.

\section{Assertion of claims arising from long-running court proceedings}

\section{Summary}

This paper deals with the issues related to the lenght of court proceedings and chronicity of litigations. It concernes constitutional and conventional regulations related to the right to the court and the right to a fair trail, from which follows the right to reasonable time of litigation. Also problems conected to compensation for pecuniary and non-pecuniary damages arrising from chronicity of litigation found their reflections in this article.

Keywords: the right to access to the court, chronicity of litigation, personal rights, damages. 